\title{
GAMBARAN FAKTOR LINGKUNGAN YANG BERPERAN PADA RUMAH YANG DITEMUKAN TUNGAU DEBU DI KOTA MANADO
}

\author{
${ }^{1}$ Indah S. M. Ikbal \\ ${ }^{2}$ Angle M. H. Sorisi \\ ${ }^{2}$ Victor D. Pijoh
}

\author{
${ }^{1}$ Kandidat Skripsi Fakultas Kedokteran Universitas Sam Ratulangi Manado \\ ${ }^{2}$ Bagian Parasitologi Fakultas Kedokteran Universitas Sam Ratulangi Manado \\ Email: i.ikbal11_112@yahoo.com
}

\begin{abstract}
The term house dust mites have been used to express the number of mites that are associated with the dust in the house. These mites can be found in mattresses, pillows, as well as other furniture. The most established population of house dust mites is in the bedroom dust, especially on the mattress. This study aimed to obtain the environmental factors that contribute to the house dust mites. This was a descriptive study. Samples were families with positive house mites, as many as 96 samples, in three villages namely Malalayang 1, Malalayang 2, and Kleak, Manado. Samples were collected by using questionnaires. The results showed the presence of mites in all respondents' houses. Some environmental factors affected the presence of dust mites in houses, as follows: mattress, sofa, floor, pets, bedcover, temperature, and humidity. It takes awareness to pay more attention to the cleanliness of the home environment.
\end{abstract}

Keywords: house dust mites, environment

\begin{abstract}
Abstrak: Istilah tungau debu rumah (TDR) telah digunakan untuk menyatakan sejumlah tungau yang ditemukan berasosiasi dengan debu di rumah-rumah tempat tinggal. Tungau ini dapat ditemukan di kasur, bantal, dan perabot rumah lainnya. Populasi TDR terbanyak didapatkan pada debu kamar tidur terutama pada debu kasur. Penelitian ini bertujuan untuk mengetahui faktor-faktor lingkungan yang berperan pada rumah yang ditemukan TDR. Penelitian ini bersifat deskriptif. Sampel penelitian ialah sebagian kepala keluarga (KK) dengan rumah yang positif tungau yaitu sebanyak 96 sampel di tiga kelurahan yaitu Malalayang 1, Malalayang 2 dan Kleak Kota Manado. Sampel dikumpulkan dengan menggunakan kuesioner. Hasil penelitian menunjukkan gambaran positif keberadaan tungau debu pada semua rumah responden. Faktor lingkungan yang berpengaruh pada keberadaan tungau debu tersebut ialah penggunaan kasur, sofa, lantai, binatang peliharaan, sprei, suhu dan kelembaban berperan pada gambaran rumah yang ditemukan tungau debu rumah. Dibutuhkan kesadaran masyarakat untuk lebih memperhatikan kebersihan lingkungan rumah.
\end{abstract}

Kata kunci: tungau debu rumah, lingkungan

Tungau Debu Rumah (TDR) merupakan penyebab penting dalam timbulnya penyakit alergi seperti asma, konjungtivitis, rhinitis, dan dermatitis atopik. ${ }^{1}$ Terdapat 2 spesies TDR yang paling umum ditemukan di seluruh dunia yaitu Dermatophagoides farina dan Dermatophagoides pteronyssinus. ${ }^{2}$ Pada penelitian lanjutannya Aulung melaporkan dari 5411 gram debu rumah diperoleh 876 tungau yang terdiri dari 7 genus. Penelitian Sundaru di Jakarta melaporkan dari 32,6 gram debu rumah 
yang berasal dari 20 rumah penderita asma, didapatkan tungau sebayak 1.480 yang terdiri atas 10 genus. Genus yang paling banyak ditemukan Dermatophagoides ialah sebanyak 582 tungau. Manan et al. melaporkan pada 10 penderita rumah penderita asma ditemukan 9 genus dan tungau yang terbanyak adalah Dermatophagoides. Di Kolombia genus Dermatophagoides juga merupakan TDR yang dominan. Cuthbert et al. yang melakukan penelitian di gudang hasil pertanian juga mendapatkan bahwa tungau yang terbanyak ialah genus Dermatophagoides. ${ }^{3}$

Populasi tungau di dalam rumah bergantung pada beberapa faktor: tinggi rendahnya rumah dari permukaan laut; daerah dengan musim panas yang lebih panjang daripada musim hujan; adanya berbagai binatang di dalam rumah; rumah yang kotor dan banyak debu; serta suhu dan kelembaban. ${ }^{4}$ Faktor-faktor fisik seperti suhu dan kelembaban merupakan faktor utama yang memengaruhi pertumbuhan dan perkem-bangan organisme dalam rumah. Tungau sangat peka terhadap kelembaban relatif. Pada kelembaban 60\% atau lebih rendah populasi TDR ditemukan sangat sedikit atau mati. Secara umum suhu optimal bagi perkembangan TDR adalah $25^{\circ}-30^{\circ} \mathrm{C}$ dan kelembaban relatif $70-80 \%{ }^{5}$

Manado terdiri atas 9 wilayah kecamatan dan 87 kelurahan. Suhu udara Kota Manado pada siang hari berkisar antara $31,4-33,7^{0} \mathrm{C}$, sedangkan suhu udara pada malam hari berkisar antara 20,7$22,7^{\circ} \mathrm{C}$ dan mempunyai kelembaban udara relatif tinggi dengan rata-rata berkisar antara $80-87 \% .^{5}$ Lingkungan yang seperti ini yang sangat baik sebagai habitat TDR. Salah satu kelurahan yang banyak terdapat pasien dengan penyakit asma, rinitis, dermatitis, dan konjungtivitis ialah Titiwungen Selatan yang terdapat di Kecamatan Sario Kota Manado. Hal ini diperkuat dari data Puskesmas Sario pada bulan Januari Agustus 2012. ${ }^{6}$

\section{METODE PENELITIAN}

Penelitian ini menggunakan metode deskriptif. Penelitian dilaksanakan pada rumah yang ditemukan TDR pada tiga kelurahan yaitu Malalayang 1, Malalayang 2, dan Kleak di Kota Manado dan berlangsung dari Oktober - Desember 2014. Untuk menentukan jumlah sampel minimal digunakan rumus untuk penelitian deskriptif kategorik.

$$
n=\frac{Z \alpha^{2} P Q}{d^{2}}
$$

$\mathrm{N}=$ jumlah sampel minimal

$\mathrm{Z}=$ tingkat kepercayaan

(untuk $Z=90 \%$, nilainya $Z \alpha=1,64$ )

$\mathrm{P}=$ proporsi sampel debu yang positif terdapat tungau

Pada penelitian sebelumnya yang dilakukan di Kota Manado, ${ }^{7}$ proporsi sampel debu yang positif terdapat tungau sekitar $90 \%$ $(0,9)$

$\mathrm{Q}=1-\mathrm{P}=0.1$

$\mathrm{D}=$ limit dari error atau presisi absolut

$$
n=\frac{(1,64)^{2} 0,9(0,1)}{(0.05)^{2}}=96
$$

Berdasarkan rumus di atas, maka besar sampel minimal untuk penelitian ini 96 sampel. Variabel penelitian yang digunakan terdiri dari karakteristik responden: umur, jenis kelamin, alamat, dan pekerjaan. Untuk lingkungan rumah responden yaitu: lama dihuni, dinding, lantai, karpet, sofa, binatang peliharaan, riwayat alergi, suhu, kelembaban, kasur dan juga bantal.

\section{HASIL PENELITIAN DAN BAHASAN}

Hasil penelitian yang dilakukan di Malalayang 1, Malalayang 2, dan Kleak Kota Manado menunjukkan responden terbanyak ialah perempuan (55 responden, 57,3\%). Dari 96 responden terdapat 37 responden berusia 20-29 tahun (38,5\%), 28 responden berusia 30-39 tahun (29,2\%), 19 responden berusia $40-49$ tahun $(19,8 \%), 5$ responden berusia $>70$ tahun $(5,2 \%), 3$ responden berusia 50-59 tahun (3,1\%), 2 responden berusia $<20$ tahun $(2,1 \%)$, dan 2 responden berusia 60-69 tahun (2,1\%). 
Mayoritas pekerjaan responden ialah mahasiswa sebanyak 26 responden (27,1\%).

Pada penelitian ini responden dengan jumlah penghuni kasur sampel 2 orang ialah 51 responden (53,1\%). Dari penelitian sebelumnya ditemukan bahwa tungau debu rumah paling banyak ditemukan di kamar karena makanan tungau debu rumah ialah serpihan kulit manusia. Dengan demikian salah satu faktor yang dapat memengaruhi populasi tungau debu rumah ialah jumlah penghuni kasur/kamar. Semakin banyak penghuni kamar, maka populasi tungau kemungkinan juga meningkat.

Dari 96 responden sebagian besar lamanya rumah dihuni 5-10 tahun, dinding rumah responden terbanyak terbuat dari tembok. Lantai rumah responden terbanyak menggunakan keramik, dan yang teratur membersihkan lantai sebanyak 74 responden dari 96 responden. Dari 74 responden, 50 responden membersihkan lantai $2 \mathrm{kali} / \mathrm{hari}$ dengan alat pembersih yang paling sering digunakan responden yaitu sapu. Dari data diatas didapatkan 11 responden yang menggunakan karpet, 9 responden tidak membersihkan karpet secara teratur serta frekuensi pembersihan karpet paling banyak 3 kali/minggu dengan banyak responden yang menggunakan sapu. Dari hasil penelitian semua responden menggunakan sofa kain, dengan lama pemakaian paling banyak 5-10 tahun sebanyak 45 responden.

Suhu dalam rumah responden terbanyak $31^{\circ} \mathrm{C}$ dengan kelembaban $85 \%$. Faktor-faktor utama yang memengaruhi pertumbuhan dan perkembangan TDR ialah suhu, kelembaban, dan persediaan makanan. Secara umum suhu dan kelembaban relatif yang optimal bagi perkembangan TDR $25-30^{\circ} \mathrm{C}$ dan $70-80 \%$. Makanan TDR ialah bahan-bahan organik yang membusuk atau jaringan tubuh organisme hidup atau mati seperti daki dan serpihan kulit manusia. Responden yang memiliki binatang peliharaan sebanyak 41 orang dengan jenis binatang peliharaan terbanyak yaitu kucing pada 16 responden.

Tungau debu rumah meskipun kecil dan sulit dilihat dengan mata telanjang dapat menjadi masalah yang serius bagi kesehatan manusia. Barbagai studi tentang alergi terhadap debu rumah di seluruh dunia menunjukkan bahwa TDR mempunyai peran penting dalam pencetus timbulnya reaksi alergi seperti asma, dermatitis atopik, danr rinitis. Bagian tubuh TDR yang bisa menjadi alergen yaitu kutikula, organ seksual dan saluran pencernaan, TDR yang sudah mati, serta tinjanya merupakan alergen yang potensial Penelitian di Jakarta pada tahun 2000 melaporkan bahwa 81,73\% penderita asma dan rhinitis alergi terhadap debu rumah.

Dari penelitian yang dilakukan didapatkan jumlah kamar tidur dengan 3 kamar tidur yaitu 33 responden, dan jenis kasur yang sering dipakai yaitu spring bed sebanyak 62 responden, dengan lama pemakaian terbanyak yaitu 5-10 tahun pada 47 responden. Semua responden menggunakan bantal. Jumlah bantal yang digunakan paling banyak yaitu 2 buah sebanyak 37 responden dan jumlah guling yang banyak digunakan yaitu 2 buah dengan 44 responden. Bahan bantal yang banyak digunakan yaitu busa dengan 90 orang responden. Semua responden menggunakan sprei; untuk penggantian sprei yang paling banyak yaitu 2 kali/minggu dengan 47 responden. Kasur yang dijemur sebanyak 33 responden, dengan frekuensi penjemuran terbanyak yaitu 2 kali/minggu untuk 13 responden. Karpet yang digunakan dalam kamar responden 19 orang. Untuk responden yang teratur membersihkan karpet sebanyak 11 responden, sedangkan frekuensi pembersihan 4 kali/minggu sebanyak 6 responden dan alat pembersih yang sering digunakan yaitu dijemur/dikibaskan sebanyak 10 responden.

Penelitian sebelumnya menunjukkan hubungan yang sangat erat antara lama penggunaan kasur kapuk dengan jumlah populasi TDR dengan arah yang positif yang artinya semakin lama penggunaan kasur kapuk akan menjadikan jumlah populasi TDR cenderung meningkat. Di Indonesia, sebagian besar masyarakat 
masih menggunakan kasur berbahan kapuk sebagai alas tidur walaupun sudah banyak juga yang beralih ke kasur berbahan non kapuk seperti kasur busa, kasur pegas, dan kasur lateks. Kasur merupakan habitat terbaik yang cocok untuk perkembangan TDR yang menyukai lingkungan yang hangat dan lembab seperti di dalam kasur. Selain itu, pada kasur juga tersedia makanan TDR (reaksi antara kasur, keringat, daki, serta serpihan kulit manusia). Kasur kapuk merupakan perabot rumah tangga yang perlu mendapat perhatian khuus karena TDR paling banyak ditemukan pada kasur dan jenis kasur kapuk yang paling banyak digunakan masyarakat di Indonesia, khususnya golongan masyarakat menengah ke bawah. Penelitian populasi TDR pada berbagai jenis kasur seperti kasur kapuk, busa dan pegas menunjukkan bahwa pada kasur kapuk paling banyak mengandung TDR terutama $D$. pteronyssinus dan $D$. farinare. Umur kasur juga menentukan lama tidaknya penurunan kadar alergen TDR. Makin lama umur kasur makin banyak investasi TDR beserta fesesnya yang masuk diantara celah-celah serat kapuk maupun pembungkusnya sehingga sukar diharapkan alergen ini akan terlepas. Kasur yang masa penggunaannya kurang dari 1 tahun jarang dihuni TDR, sedangkan kasur yang masa penggunaannya 2-4 tahun sering dihuni TDR. Hal ini disebabkan karena keadaan kasur kapuk yang umurnya kurang dari 1 tahun umumnya masih baik karena reaksi antara daki, keringat dan kapuk masih ringan, sedangkan kasur yang berumur 4 tahun telah kumuh karena terjadi reaksi antara daki, keringat dan kasur kapuk yang telah berlangsung lama. ${ }^{8}$

\section{SIMPULAN}

Berdasarkan hasil penelitian dapat disimpulkan bahwa faktor penggunaan kasur, sofa, lantai, binatang peliharaan, sprei, suhu dan kelembaban berperan pada gambaran rumah yang ditemukan tungau debu rumah.

\section{DAFTAR PUSTAKA}

1. Natadisastra D, Agoes R. Parasitologi kedokteran ditinjau dari organ tubuh yang diserang. Jakarta: EGC, 2009.

2. Santosa H. Asma bronkial. In: Akib AAP, Matondang CS, penyunting. Buku Ajar Alergi Imunologi Anak, Jakarta: BP IDAI, 1996; p. 179-99.

3. Noble ER, Noble GA. Parasitology, the Biology of Animal Parasites. Philadelphia: Lea \& Febiger, 1971.

4. Zulkoni Akhsin. Parasitologi. Yogyakarta: Nuha Medika, 2010.

5. Baratawidjaya KG. Reaksi hipersensitivitas. In: Imunologi dasar (Edisi ke-7). Jakarta: Balai penerbit FKUI, 2006; p. 157-61.

6. Quillen DM, Feller DB. Diagnosis rhinitis: allergic vs non allergic. Am Fam Physician. 2006;73:1583-90.

7. Yudopranoto K. Perbandingan populasi tungau debu rumah pada kasur kapuk dan non-kapuk di perumahan PJKA Kelurahan Randusari Semarang Selatan Jawa Tengah [Skripsi]. Semarang: Universitas Diponegoro, 2006.

8. Faiza A. Hubungan antara lama penggunaan kasur kapuk dengan jumlah populasi tungau debu rumah diperumahan PJKA Kelurahan Randusari Semarang [Skripsi]. Semarang: Universitas Diponegoro, 2006. 